\title{
Miradas recientes sobre/desde el peronismo en el cine argentino de ficción
}

\section{Recent views on/from Peronism in Argentine fiction cinema}

\section{Alfredo Dillon ${ }^{1}$}

Instituto de Investigaciones, Facultad de Ciencias Sociales, Universidad Católica Argen-

tina. Buenos Aires, Argentina

alfredodillon@yahoo.com

ORCID 0000-0001-7571-6693

Citar como: Dillon, A. (2020). Miradas recientes sobre/desde el peronismo en el cine argentino de ficción. Desde el Sur, 12(2), pp. 525-545.

\section{RESUMEN}

El artículo realiza un análisis formal y narrativo de dos películas biográficas recientes sobre el peronismo: Juan y Eva (Paula de Luque, 2011) y Puerta de hierro. El exilio de Perón (Víctor Laplace y Dieguillo Fernández, 2012). Ambos films son leídos en relación con el clima de época que comparten: el del tercer gobierno kirchnerista en la Argentina. Construidas a partir de dos estéticas narrativas contrapuestas — una posépica minimalista por un lado, una recuperación discursiva de la épica peronista por el otro-, las dos películas comparten, sin embargo, una mirada idealizadora sobre las figuras de Juan Domingo y Eva Perón.

\section{PALABRAS CLAVE}

Cine argentino, peronismo, biopic, cine biográfico, cine histórico

\section{ABSTRACT}

The article offers a formal and narrative analysis of two recent biographical films about Peronism: Juan y Eva

1 Investigador del Instituto de Investigaciones de la Facultad de Ciencias Sociales de la Universidad Católica Argentina (UCA). Doctor en Ciencias Sociales por la Universidad de Buenos Aires (UBA), con una tesis sobre cine argentino contemporáneo. Es licenciado y profesor en Letras (UBA) y enseña en las carreras de Comunicación de la UCA desde 2006. Ha publicado libros y diversos artículos sobre cine argentino en revistas académicas. 
(Paula de Luque, 2011) and Iron Gate. The Exile of Perón (Víctor Laplace and Dieguillo Fernández, 2012). Both films are read in relation to the political climate they share: that of the third Kirchner government in Argentina. Produced in two opposing narrative aesthetics - a minimalist postepic on the one hand, a discursive recovery of the Peronist epic on the other - the two films, however, share an idealizing view of the figures of Juan Domingo and Eva Perón.

\section{KEYWORDS}

Argentine Cinema, Peronism, Biopic, Biographical Cinema, Historical Cinema

\section{Introducción}

Junto con José de San Martín, Juan y Eva Perón figuran entre los personajes históricos más retomados por el cine argentino. Pero mientras el Libertador suele invocarse desde las más diversas posiciones ideológicas como una figura que garantizaría un punto de referencia común a la identidad argentina, «más allá» de todas las antinomias y discrepancias (Kohan, 2005, p. 16), las figuras de Perón y Evita no suscitan esa unanimidad. A diferencia de San Martín, generan adhesiones pero también rechazos: esa polarización se reactualizará con los gobiernos de Néstor Kirchner (2003-2007) y, particularmente, Cristina Fernández de Kirchner (2007-2015).

Las primeras películas sobre Evita fueron documentales estrenados poco después de su muerte en 1952, durante el segundo gobierno peronista, y ya apuntan a construir su inmortalidad (Cortés Rocca y Kohan, 1998, p. 58). Desde entonces su figura ha sido recuperada de diferentes maneras en los años 70, 80, 90 y luego de 2003. La figura de Juan Domingo Perón, en cambio, no ha recibido la misma atención cinematográfica. Sin embargo, en la última década y en el marco de un nuevo gobierno peronista —el encabezado por Cristina Fernández de Kirchner-, Perón empezó a ser recuperado en términos similares a los que, hasta los años 90, habían sido exclusivos de Eva.

En este artículo abordaremos dos biopics del cine argentino reciente enfocados en estos personajes: Juan y Eva (2011), escrito y dirigido por Paula de Luque, y Puerta de hierro. El exilio de Perón (2012), escrito, dirigido y protagonizado por Víctor Laplace (con la colaboración de Dieguillo Fernández en la dirección y de Leonel D’Agostino en el guion). Del amplio corpus de películas sobre el peronismo, elegimos estas dos porque comparten un clima de época - el del segundo gobierno de Cristina Fernández de Kirchner, tras el Bicentenario y la muerte de Néstor Kirchner en 
2010 - y porque constituyen biopics propiamente dichos: son «films de ficción enfocados en personajes cuya existencia histórica está documentada» (Vidal, 2014, p. 3).

\section{Juan y Eva en tiempos de Cristina}

Como todo ejercicio de memoria, estos biopics recuperan las figuras de Juan Domingo y Eva Perón para proponer una relectura del pasado - en este caso, del peronismo - desde el presente. Cada película pone el foco en un periodo diferente de la historia argentina: Juan y Eva relata los dos años previos al 17 de octubre de 1945, antes que estos dos personajes se convirtieran en Perón y Evita, y pone el foco en el nacimiento y la consolidación del romance entre ellos. Puerta de hierro, por su parte, abarca un periodo más amplio y menos explorado por el cine de ficción: el del exilio de Perón, desde 1955 hasta 1972. En el contexto del kirchnerismo, estos films vuelven sobre el peronismo para contar la historia del matrimonio político más importante del siglo XX argentino.

«La multiplicación de producciones desde la perspectiva peronista suele promover, en cada ocasión, interpretaciones que las relacionan con una más o menos solapada "operación" política», escribe Amado (2009, p. 59) al repasar la prolífica relación entre cine y peronismo. Amado cuestiona este tipo de lecturas, que para ella se fundan en el rechazo o la desconfianza hacia el peronismo. En el caso de los dos films que nos ocupan, sin embargo, las conexiones con la esfera gubernamental son claras, lo que exige pensarlos no solo en términos estéticos, sino también a la luz del contexto político en el que emergen.

La directora de Juan y Eva, Paula de Luque, fue convocada por el oficialismo en 2012 para realizar el documental Néstor Kirchner, la película, luego de que el director original, Adrián Caetano, se distanciara de la producción. El guion de Juan y Eva está inspirado en la novela homónima de Jorge Coscia, quien ocupó el cargo de secretario de Cultura de la Nación entre 2009 y 2014. En los créditos, los primeros agradecimientos se dirigen a «Casa Rosada» y a Oscar Parrilli, secretario general de la Presidencia entre 2003 y 2014. Por su parte, Puerta de hierro contó con el apoyo de los gobiernos peronistas de las provincias de Buenos Aires, San Juan, Entre Ríos, Formosa, Chubut y Mendoza, además de la localidad bonaerense de Tigre.

Casi a la manera de las franquicias cinematográficas de superhéroes como DC Comics o Marvel, que sistemáticamente amplían sus galerías de personajes, las nuevas aproximaciones fílmicas al peronismo expanden el repertorio de personajes que habían circulado por las películas anteriores: más allá de las figuras centrales de Eva y Juan Domingo Perón, el universo narrativo peronista incorpora también a los hermanos de Evita, 
John William Cooke (referente del peronismo de izquierda), Jorge Antonio (empresario y asesor de Perón en el exilio), Héctor José Cámpora (presidente durante dos meses, entre mayo y julio de 1973), Rodolfo Galimberti (dirigente guerrillero de Montoneros y luego empresario) y hasta el escritor Rodolfo Walsh (protagonista de Eva de la Argentina, film de animación estrenado en 2011). Según el esquema actancial de Greimas (1971), todos estos personajes operan como ayudantes de los protagonistas (Eva y/o Juan Perón); del lado de los oponentes, en cambio, aparecen el embajador estadounidense Spruille Braden, el sindicalista Augusto Timoteo Vandor, María Estela Martínez («lsabel») y José López Rega.

\section{Breve recorrido histórico}

«La mayoría de los argentinos me mira como una estatua de mármol. Otros, como el tirano. Los más jóvenes, como el Viejo. Los más cercanos, como el hombre que está a punto de morir y del que tienen que asegurarse la herencia», dice el Perón que compone Víctor Laplace en Puerta de hierro. Se refiere a las múltiples miradas sobre este líder político, que corresponden a las diversas facetas que prefieren destacar distintos grupos en relación con uno de los personajes centrales de la política argentina en el siglo XX (y en lo que va del siglo XXI).

Esa multiplicidad de rostros de Perón y de Eva también se ha visto reflejada en el cine, que ha presentado distintas miradas sobre estos personajes a lo largo del tiempo, pero también en la televisión, en la literatura y en el teatro (Navarro, 2002). Trombetta reseña tres «variantes míticas» en relación con la figura de Evita: la mujer del látigo, la mártir y la Eva-Che, es decir, la heroína épica $(2015$, p. 8). También es necesario mencionar el influyente libro Cine y peronismo, de Clara Kriger, así como las reflexiones de Ana Amado en La imagen justa, entre otras investigaciones.

Los primeros documentales sobre Evita fueron realizados durante el segundo gobierno peronista (1952-1955), con una clara intención propagandística: Eva Perón inmortal (Luis Cesar Amadori, 1952), Y la Argentina detuvo su corazón (Edward Cronjager, 1952), centrado en los funerales de Evita, y Su obra de amor (Carlos Borcosque, 1953), sobre la vida política de Eva Perón y la fundación que dirigió. Las tres películas fueron producidas por la Subsecretaría de Prensa y Difusión, a cargo de Raúl Apold (quien constituye otro de los personajes del universo narrativo peronista). Kriger identifica también en la década de 1950 la producción de los primeros docudramas peronistas: documentales en los que se incorporan actores para interpretar escenas de ficción que reconstruyen acontecimientos históricos. Según Kriger, el docudrama «juega con los límites nunca ciertos entre la ficción y el documental, reconstruyendo, reescenificando y reinterpretando» (2009, p. 116). 
En los años 70 hay algunos films documentales - como Una mujer, un pueblo (Carlos Luis Serrano, 1970), o los fragmentos sobre Perón y Evita en La hora de los hornos (Pino Solanas y Octavio Getino, 1973) - , mientras que la hibridación entre ficción y documental adquiere nuevas formas en las películas estrenadas a partir de 1983. En estos años la figura de Eva ha suscitado mayor interés que la de Perón: el primer film que debemos mencionar en el periodo democrático es Evita, quien quiera oír que oiga (1984), la ópera prima de Eduardo Mignogna, protagonizada por Flavia Palmiero. La película incorpora imágenes de archivo, testimonios y entrevistas a historiadores, escritores y filósofos que analizan el «mito» de Evita. Esas imágenes se intercalan con la ficcionalización del viaje en tren de Evita desde Junín hacia la ciudad de Buenos Aires. En esas escenas ficcionales, sin diálogo, Evita es interpretada por Flavia Palmiero. En relación con esta película, López y Rodríguez escriben: «La Evita íntima nace para el cine con este filme. A través de estas reconstrucciones ficcionales se recrean momentos de su infancia y de su juventud. Por primera vez espiamos a Eva Duarte antes de ser Evita» (2009, p. 174).

El primer biopic de Evita propiamente dicho -es decir, planteado como film de ficción, aunque incorpore imágenes documentales- es Eva Perón (1996), también conocido como Eva Perón: la verdadera historia. Dirigida por Juan Carlos Desanzo y escrita por José Pablo Feinmann, esta película construyó la versión de Evita que hoy podría considerarse más canónica, interpretada por Esther Goris, mientras que Víctor Laplace encarnó allí por primera vez a Juan Domingo Perón. El subtítulo «la verdadera historia» constituye un doble gesto de intertextualidad: por un lado, remite a la banda sonora de Evita, quien quiera oír que oiga (donde la letra de Lito Nebbia decía «Si la historia la escriben los que ganan, / eso quiere decir que hay otra historia: / la verdadera historia. Quien quiera oír que oiga»). Por el otro, es una clara respuesta a Evita (1996), la película musical escrita y dirigida por Alan Parker y protagonizada por Madonna, a partir de la ópera rock de Andrew Lloyd Webber y Tim Rice estrenada en Londres en 1978.

Parafraseando la letra de la canción, si la versión de Desanzo ofrece la verdadera historia, eso quiere decir que la película de Parker ofrecía una falsa versión de Evita: Madonna compone allí a una trepadora sin escrúpulos ni conciencia política, en el marco de un guion que renuncia a todo rigor histórico ${ }^{2}$ y cuya mayor licencia es la incorporación del Che

2 El guion de Alan Parker estaba basado en el musical de Andrew Lloyd Webber y Tim Rice, que a su vez se basó en el libro The woman with the whip, de Mary Main, publicado originalmente en Nueva York en 1952 y editado en Buenos Aires en 1955, bajo el título La mujer del látigo. 
(que evidentemente alude a Ernesto Guevara) como personaje y narrador, interpretado por Antonio Banderas. Aunque el film estadounidense tiene una posición antiperonista - y machista-, comparte con la versión de Desanzo la referencia a algunos episodios centrales de la vida de Evita que serán retomados en sus distintas biografías, como el velorio del padre —donde Evita y su familia son rechazados por ser «ilegítimos», un rechazo en el que las narraciones cifran la conciencia de clase de la protagonista—, así como la gira por Europa en 1947, el «Cabildo Abierto» y la renuncia a la candidatura como vicepresidenta en 1951, y la enfermedad que acabó con su vida en 1952.

En la década siguiente, Héctor Olivera, otro director clave del cine argentino de los 80, estrena Ay, Juancito (2004) durante el segundo año del gobierno de Néstor Kirchner. La película se enfoca en Juan Duarte, el único hermano varón de Evita, presentado como un mujeriego, derrochador y corrupto. Duarte es interpretado por Adrián Navarro, mientras que Evita y Perón son personajes secundarios a cargo de Laura Novoa y Jorge Marrale. Ay, Juancito y Eva Perón no solo comparten guionista (José Pablo Feinmann), sino también la voluntad de denunciar ciertos aspectos de la versión neoliberal del peronismo que gobernó el país durante la década de 1990. De esta manera, los films toman distancia con respecto a la estética del Nuevo Cine Argentino que emergió en esos años, ajeno a la «demanda política» (Aguilar, 2010, p. 23) y al «discurso político explícito» (Prysthon, 2013, p. 95). En 1996, la película de Desanzo recupera a Evita para formular una crítica a la renuncia del menemismo a las banderas sociales del peronismo y el abandono de los sectores populares. La película termina con el pedido de Evita a Perón (y, por extensión, al peronismo): «No abandones nunca a los pobres» ${ }^{3}$.

\section{Biopic y cine biográfico}

Los biopics son películas de ficción que dramatizan una porción de la historia de vida de una o varias personas cuya existencia real está acreditada. Dentro del cine biográfico incluimos documentales centrados en biografías (de personajes históricos, artistas, deportistas, criminales, etc.); el biopic, en cambio, se presenta como un film de ficción basado en hechos reales. Podemos pensar el biopic como una ficción híbrida, de igual manera que los documentales biográficos muchas veces incorporan ficcionalizaciones. Preferimos el término biopic antes que biofilm (Rosenstone,

3 Según reconstruye Galasso (2005, p. 604) a partir de un testimonio del propio Juan Domingo Perón, la frase fue efectivamente pronunciada por Evita en su lecho de muerte: «No abandones nunca a los pobres. Son los únicos que saben ser fieles». 
2006) porque el segundo abarca también películas documentales, mientras que nuestros objetos de análisis son ficciones biográficas.

Los orígenes del biopic pueden rastrearse hasta los comienzos de la historia del cine (Altman, 2000; Fontanel, 2016), tanto en Estados Unidos como en Argentina. El actual boom del género, por lo tanto, no puede pensarse como la irrupción de un fenómeno cultural nuevo, sino en todo caso como un incremento de la popularidad del género en las últimas décadas, en el marco de cambios culturales más amplios, que han sido pensados en términos de retornos (de lo real, del sujeto, del relato, etc.) y de giros (subjetivo, biográfico, intimista, etc.).

La proliferación de biopics atraviesa los lenguajes audiovisuales más allá del cine: el éxito reciente de series televisivas biográficas basadas en figuras de artistas (Luis Miguel, Sandro, Nicky Jam), criminales (Pablo Escobar, el «Chapo» Guzmán, el clan Puccio) o personajes históricos (de Marco Polo a sor Juana Inés de la (ruz) da cuenta de que estamos ante una tendencia transversal a las narrativas audiovisuales. En algunos casos, los biopics exploran los aspectos más polémicos de los personajes, mientras que en otros la biografía asume la forma del homenaje (Sánchez Noriega, 2012, p. 80).

La bibliografía sobre biopic suele coincidir en señalar el libro de George Custen, Bio/pics: How Hollywood constructed public history (1992), como el trabajo pionero sobre el tema. El autor ya advertía sobre la subestimación del género, a la vez que reivindicaba su importancia en la construcción de la historia pública. Custen define el biopic a partir de su foco «en la vida, o la porción de una vida, de una persona real cuyo nombre real es utilizado» (Custen, 1992, p. 6). El texto identifica algunos elementos recurrentes en el biopic clásico, como el uso del flashback, la voz en off (en ciertos casos, voice over), y la oposición entre el sujeto y su familia, entre otros.

Otro académico estadounidense, Dennis Bingham, afirma que el biopic «narra, exhibe y celebra la vida de un sujeto con el fin de demostrar, investigar o cuestionar su importancia en el mundo» (Bingham, 2010, p. 10). El libro de Bingham, Whose lives are they anyway?, se divide en dos partes: una para los biopics sobre hombres, y otra para los biopics sobre mujeres. Según el autor, la principal diferencia entre ambas tiene que ver con la mayor rigidez del biopic femenino y con la tendencia de estos films a victimizar a la protagonista, mientras que el biopic masculino habría incorporado una mayor variedad de inflexiones durante el último siglo, desde las formas celebratorias hasta la parodia o la indagación crítica acerca de los personajes. 
Esta diferencia entre biopic masculina y biopic femenina ha sido relativizada en trabajos posteriores, como el de Polaschek (2013), que señala una reconfiguración del género a partir de los años 80 , con la creciente presencia de mujeres directoras en Hollywood y la aparición de un nuevo subgénero: el biopic «posfeminista». A partir de cuatro películas biográficas de la década del 2000 — sobre Sylvia Plath, Frida Kahlo, Virginia Woolf y Jane Austen-, Polaschek afirma que en estos biopics posfeministas la mujer ya no resulta victimizada, sino que se deconstruyen las representaciones femeninas tradicionales y se desdibujan las fronteras entre el modo de tratamiento de personajes femeninos y masculinos. En este sentido, los biopics sobre Eva Perón de los años 80 y 90 se anticipan a esta tendencia señalada por la autora.

La genealogía del interés del biopic por los individuos «excepcionales» puede rastrearse en el romanticismo y su concepción del genio creador, o en las ideas de Carlyle y Hegel acerca de los «grandes hombres» —los héroes - como los verdaderos hacedores de la historia. En una época que ha sido caracterizada a partir de la «caída de los grandes relatos» (Lyotard, 1989), el auge del biopic podría leerse casi como una compensación: es el género en el que esos grandes relatos -ya no colectivos, sino protagonizados por grandes individuos- persisten.

El interés contemporáneo en el biopic se inscribe en un contexto más amplio: la biografía en sus diversas formas y enfoques ha ocupado el centro de la escena en los debates de la teoría literaria, la historia, los estudios culturales y las ciencias sociales. Este movimiento ha sido categorizado como un "giro subjetivo» (Sarlo, 2005) o "giro biográfico» (Arfuch, 2002); estos procesos son correlativos del boom que experimentaron en los últimos 20 años el testimonio, la autobiografía, la crónica y otros géneros del yo. En el campo cinematográfico, ese boom contribuye a explicar el interés en el género biográfico, pero también se expresó en un auge del documental -en particular, del documental en primera persona-y en la proliferación global de «nuevos realismos».

\section{Juan y Eva: la mirada íntima}

Paula de Luque adapta en Juan y Eva la novela homónima de Jorge Coscia. Al final de la película, una leyenda aclara que los acontecimientos y personajes «están basados en hechos reales de la historia argentina; sin embargo están narrados libremente de modo ficcional». En otras palabras, el pacto que propone el biopic implica el despliegue de hechos y personajes reales; a la vez, el film reivindica una narración ficcional libre. Al poner el foco en la intimidad de la pareja, la película elige representar situaciones en las que predomina la invención. En 2011, Juan y Eva se ubicó novena 
entre las producciones argentinas más vistas del año, con 66795 espectadores (INCAA, 2011).

La narración abarca dos años: desde que el coronel Juan Domingo Perón (Osmar Núñez) y la actriz Eva Duarte (Julieta Díaz) se conocen, tras el terremoto ocurrido en San Juan el 15 de enero de 1944, hasta el 17 de octubre de 1945, hito que determina la conversión definitiva de «Juan» en «Perón» y, correlativamente, de «Eva» en «Evita». De ahí el título del film: la película se detiene en estos personajes antes de que se vuelvan figuras históricas. A diferencia de la mayoría de los biopics sobre Evita - y de Puerta de hierro-, la película de De Luque no utiliza el flashback, sino que se instala en el presente de los años 1944-1945.

La operación es similar a la que realizan Walter Salles (director) y José Rivera (guionista) en Diarios de motocicleta (2004), sobre el viaje de juventud de Ernesto Guevara cuando aún no era el «Che»: se trata de mostrar al individuo antes que se convierta en mito, al hombre común y no al «gran hombre» de trascendencia histórica. Aguilar piensa esta operación como un modo «posépico» de procesar la historia nacional: «La posépica se interesa en un momento previo, en el que el personaje todavía no se ubicó en ese lugar de condensación y reflejo. Aunque virtualmente sea un gran hombre, nosotros vemos lo irreductible de su carácter» (2015, p. 251). La posépica facilitaría uno de los mayores desafíos de las películas biográficas: permitir la identificación del espectador con un personaje que no es un sujeto «común y corriente» (Arlanch, 2006, p. 38).

Esencialmente Juan y Eva es una historia de amor. La película se divide en tres partes: «El amor», «El odio» y «La revolución». La primera parte narra el comienzo del romance entre los personajes y define un tono: el del drama romántico intimista. La cámara ofrece acceso total a la intimidad del romance: vemos a Juan y Eva en la cama, sus viajes románticos, la mudanza y posterior convivencia, el cumpleaños de Juan, la complicidad cotidiana en el departamento - que constituye el espacio privilegiado de la narración-. Con excepción de la Evita (muda) de Flavia Palmiero, estamos frente a la versión más silenciosa de este matrimonio que el cine haya ofrecido. De todos modos, el film recupera algunos elementos recurrentes en los biopics anteriores de Evita, como el terremoto de San Juan (con imágenes de archivo) y el posterior festival solidario en el Luna Park.

La elección de una actriz popular - Julieta Díaz- como protagonista, en contraposición con la cara menos conocida de Osmar Núñez, contribuye a destacar a Eva por encima de Juan a lo largo del film. Díaz se suma 
así a la larga lista de actrices - y actores ${ }^{4}$ - que han interpretado a Evita: la suya no es una Eva militante (como la de Esther Goris), ni una dama de hierro (como la de Laura Novoa); tampoco una trepadora (como la de Madonna), ni una ingenua (como la de Flavia Palmiero). A diferencia de otras actrices que han emulado la gestualidad y la entonación del personaje histórico, la actuación de Julieta Díaz no se diferencia demasiado de otros personajes que ella ha interpretado: Eva es aquí, ante todo, una mujer como cualquier otra.

Aunque está construida sobre la idea de la mujer común, ciertos elementos prefiguran la excepcionalidad de Evita: en el comienzo se la muestra actuando en el ciclo de radioteatro «Grandes mujeres de la historia universal», donde interpreta a Carlota de México, de quien se afirma que estuvo al lado de un hombre muy poderoso (el emperador Maximiliano) y que «fue capaz de dar todo por amor».

A diferencia de lo que sucedía en Diarios de motocicleta, el film de De Luque no ofrece elementos que permitan comprender la posterior transformación de Eva en Evita. Sí se nos muestra, por ejemplo, el momento en que Eva se tiñe el pelo de rubio, en un paso hacia la configuración de su imagen icónica. Incluso ese cambio capilar es interpretado a la luz del amor hacia Perón, como parte del proceso de seducción: «Si a Perón no le gusta, te mato», le dice al peluquero.

Recién en la última parte de la película empieza a aparecer una Eva un poco más combativa; sin embargo, su lucha no es la reivindicación de los trabajadores, sino una defensa incondicional de su pareja. Al final del film, una placa señala: «Eva abandonó su carrera como actriz y se dedicó por entero al compromiso social con los más pobres; se transformó en la abanderada de los humildes». La credibilidad de esa afirmación se funda exclusivamente en el saber previo que el biopic presupone: nada de esto se anticipa en la construcción narrativa del film, ya que en ninguna escena se ha mostrado el interés de Eva por los pobres.

El film de De Luque se caracteriza por el minimalismo de la puesta en escena: no hay una gran inversión en la reconstrucción histórica, sino que predominan los interiores y los planos cerrados. La película apela a una estética que caracterizó al Nuevo Cine Argentino (Prividera, 2016, p. 37), para contar una historia que tematiza la política ( $y$, que, en ese sentido, resulta ajena a los intereses narrativos del NCA). En la construcción de ese minimalismo tienen un rol clave las actuaciones, así como la música original de Iván Wyszogrod, que contribuye al tono intimista del film.

4 La obra teatral de Copi, Eva Perón (1970), construye una Evita travesti, interpretada siempre por varones. 
La segunda parte, «El odio», comienza con el ascenso de Perón a la vicepresidencia en julio de 1944. La película señala que las pasiones -a favor y en contra - que desata el peronismo no empiezan con la primera presidencia de Perón, sino con las medidas sociales que tomó en la Secretaría de Trabajo: ahí estaría el verdadero núcleo del peronismo. Esa hipótesis se explicita en una de las placas que cierran el film: «Las transformaciones sociales que inició desde la Secretaría de Trabajo lo consolidaron como uno de los líderes más importantes del siglo XX». En el film, esas transformaciones permanecen fuera de campo; ni siquiera ingresan al discurso de los personajes.

Llamativamente, el «odio» aparece antes que la «revolución», y se refiere aquí sobre todo al desprecio que los militares sentían hacia Eva. El film explica ese odio por una diferencia de clase, pero sobre todo por una cuestión de moral sexual. «No es la mujer que se espera al lado de un hombre como usted, es una comediante», reprocha un ministro en nombre de la moral militar. Por otra parte, el odio hacia Juan resulta condensado en la figura del embajador Braden, caricaturizado por Alfredo Casero. Los militares y Estados Unidos conforman, entonces, el binomio desde donde emana el odio a Juan y Eva.

La tercera parte de la película, «La revolución», se centra en los acontecimientos que condujeron al 17 de octubre de 1945, fecha fundacional del peronismo (Plotkin, 2007). Al igual que en Puerta de hierro, el peronismo es conceptualizado como una «revolución pacífica». En una escena Perón alude a la Revolución rusa y afirma, delante de varios militares: «Si nosotros no hacemos la revolución pacífica, el pueblo hará la revolución violenta», frase tomada literalmente de un discurso pronunciado en el Colegio Militar el 7 de agosto de 1945.

En este tercer capítulo, el film modifica el pacto de lectura: se despega de la narración ficcional libre $y$, al incorporar imágenes de archivo, se acerca al documental histórico. Hacia el final, para contar la jornada del 17 de octubre, la película abandona el color y adopta el blanco y negro, de manera que las escenas ficcionales se confunden con imágenes de archivo - tomadas de los noticieros cinematográficos Sucesos argentinos y Noticiario panamericano- de los obreros copando las calles de la ciudad de Buenos Aires y marchando hacia la plaza de Mayo. Estas imágenes permiten reponer la presencia indicial del pasado y ponen en juego una estrategia que ya había sido utilizada no solo en los documentales sobre Evita y Perón, sino también en el biopic de Desanzo-Feinmann.

La narración de la jornada histórica (pública) concluye cuando Perón avanza hacia el balcón de la Casa Rosada y desde ahí saluda, con su clásico gesto de los dos brazos en alto, a la multitud congregada en la plaza 
de Mayo. Pero la película no termina en la épica del balcón, ni siquiera muestra el discurso del líder ante las masas: antes que Perón empiece a hablar, hay un corte directo y luego vemos su regreso al espacio (íntimo) del departamento, donde lo espera Eva. Lo último que vemos es la mirada silenciosa de Eva a Juan: en esa mirada se condensa la anticipación de que empieza una nueva etapa, para Juan y Eva y para la Argentina. Luego la narración nos dirá en una placa informativa: «Cinco días después, el 22 de octubre de 1945, Juan y Eva se casaron en la ciudad de Junín». En esos cinco días de octubre se cifra, según la lectura de De Luque, el corazón del peronismo, la verdadera historia de amor que el film narra: la de Perón, Evita y el pueblo.

Al final del film, una serie de placas subraya la vigencia de ambas figuras en el presente: la de Juan («El peronismo sigue siendo la identidad política de millones de argentinos») y la de Eva («Aún hoy, millones de argentinos levantan sus banderas»). El vínculo con el presente de la exhibición (2011) se hizo explícito también en algunas intervenciones públicas de la directora, quien reencuentra en Néstor y Cristina Kirchner una ecuación de amor, odio y revolución similar a la que se articula en torno a Perón y Evita:

[Cristina Fernández de Kirchner] más que nadie sabe de qué hablo cuando hablo de ese amor que trasciende las paredes y se derrama sobre el pueblo. Pero la historia se repite una y otra vez y considero que el mismo odio que se derramó sobre Cristina y Néstor proviene de los mismos sectores, los mismos intereses y la misma ignorancia de aquellos que odiaron a Perón y a Eva (De Luque, 2011).

A diferencia de otras aproximaciones cinematográficas a estos personajes, como Evita, quien quiera oír que oiga o incluso la Eva Perón de Desanzo, en Juan y Eva no hay una pretensión de objetividad ni una búsqueda de imparcialidad. El film evidencia su condición militante, no solo en su construcción narrativa sino también a partir de las conexiones de sus productores con la esfera gubernamental. De todos modos, como en el cine de Leonardo Favio - a quien está dedicada la película-, la posición militante no juega aquí en detrimento del rigor estético: por su mismo planteo narrativo, Juan y Eva no es una película panfletaria sino un film minimalista, que se asoma a la intimidad de dos personajes públicos. De esa manera, facilita la identificación del público y ejerce una pretensión habitual en el género biográfico: la construcción de un cierto modelo de ciudadanía (Fontanel, 2016). 


\section{Puerta de hierro: la figuración del prócer}

Estrenada en 2013, Puerta de hierro. El exilio de Perón se presenta como un proyecto personal de Víctor Laplace, quien dirige, escribe, protagoniza y hasta interpreta su propia versión del tango «Volver» (en un gesto que superpone a Perón con otro mito de la argentinidad, Carlos Gardel ${ }^{5}$ ). La película alcanzó 110746 espectadores y quedó séptima entre las películas argentinas más vistas del año (INCAA, 2013).

Puerta de hierro puede leerse como una secuela de la Eva Perón de 1996, donde Laplace había interpretado por primera vez a Juan Domingo Perón. El film de Desanzo terminaba con la muerte de Evita el 26 de julio de 1952; el de Laplace y Dieguillo Fernández comienza el 16 de junio de 1955, con el bombardeo a la plaza de Mayo que intentó derrocar a Perón y dejó 300 civiles muertos.

En setiembre de 1955, Perón abandona el poder y comienza su exilio, que se extenderá hasta el 17 de noviembre de 1972. Ese es el recorte temporal que traza la película: los 17 años que Perón vivió fuera de la Argentina, sobre todo en Madrid (la película fue filmada entre España y Buenos Aires). Aunque la narración sigue el punto de vista de Perón en su casa madrileña, los acontecimientos de la historia nacional de aquellos años se van incorporando por medio de referencias verbales: los fusilamientos de José León Suárez, el secuestro y desaparición del estudiante Felipe Vallese, el golpe a Arturo Illia, el Cordobazo, etc.

Se trata, en efecto, de una película eminentemente discursiva, en la que todo lo relevante sucede en los diálogos o en la voz en off. Concebido como un vehículo de información, el guion de Laplace y Leonel D'Agostino recurre a múltiples documentos históricos, sobre todo las cartas y escritos de Perón en el exilio. Algunas de las fuentes incorporadas a los diálogos son la «Carta a los compañeros peronistas» (1964), la entrevista realizada por Getino y Solanas (1971), la "Carta a Rodolfo Arce» (1966), mensajes radiales grabados por Perón, su «Mensaje ambiental a los pueblos y gobiernos del mundo» (1972); también la «Carta de los Montoneros a Perón» (1971) y el comunicado de Blanca y Erminda Duarte sobre el estado del cadáver de Eva Perón.

La incorporación textual de estas fuentes históricas a los diálogos resulta en la construcción de largos parlamentos que resultan artificiales: en

5 La letra de «Volver», de Gardel y Alfredo Le Pera, dice, en una coincidencia casi exacta con la duración del exilio de Perón, que "veinte años no es nada». En una escena, Isabel compara la sonrisa de Perón con la de Gardel; la relación entre ambas figuras a partir del exilio también remite a un film de otro director peronista: El exilio de Gardel (1986) de Fernando «Pino» Solanas. 
su vida cotidiana, Perón habla como si estuviera disertando. La selección de las fuentes, además, elimina todo equívoco: Perón explica en voz alta las razones de cada una de sus decisiones (y esas razones siempre son nobles y altisonantes). En este sentido, la película pone en juego uno de los rasgos más frecuentes de los biopics políticos: la construcción de la ejemplaridad del protagonista (Hernández Corchete, 2011).

En contraposición con Juan y Eva, aquí la épica regresa, aunque solo en el discurso. Perón habla de sí mismo en términos épicos, pero no lo vemos ejecutando ninguna hazaña: estas siempre se ubican en el pasado. En ese sentido, su heroísmo resulta paradójico: en rigor, lo propio del héroe es la acción (Blanchot, 1974, p. 572). Aunque ambos films priorizan el espacio doméstico, la película de Laplace no nos muestra un Perón íntimo, sino al Perón público en un espacio privado: como el héroe épico, es un sujeto sin fisuras, siempre idéntico a sí mismo.

En Puerta de hierro Laplace pretende «corregir» al Perón que él mismo había interpretado en 1996. Aquel era un hombre más ambiguo, que incluso parecía desconfiar de la creciente popularidad de su mujer; este, en cambio, no solo ha crecido en edad sino también en devoción hacia Evita (ya fallecida). El Perón del exilio aparece como un líder sin ambivalencias ni fisuras, tan idealizado por el guion como la Evita que él mismo evoca. Entre sus múltiples virtudes se destaca la misericordia —es un Perón conciliador - y la visión de futuro - por ejemplo, anticipa el calentamiento global- Es a la vez un revolucionario y un pacifista: hacia el final, justo antes de volver a la Argentina, afirma que «es necesaria la revolución en paz y armonía».

Según la lectura que propone el film, esa convicción pacifista permite explicar la caída de Perón en 1955: el líder renuncia para evitar un mayor derramamiento de sangre. En una escena, el médico Puigvert (interpretado por Federico Luppi) le pregunta a Perón por el derrocamiento, y el protagonista le responde: «Hay dos maneras de ganar una batalla: con sangre o con tiempo. Yo prefiero que no se derrame sangre». Esa confianza en el tiempo antes que en la sangre es una de las ideas centrales del pensamiento peronista que el film recupera, delineando de esa manera la posición de Perón frente a la violencia (de derecha o de izquierda). Hacia el final, el general cita a Mao Tse Tung para tomar distancia no solo de la violencia de 1955, sino sobre todo de la que proliferaba en los años 70: «La política es una guerra sin efusión de sangre. La guerra, una política con efusión de sangre».

El guion insiste con la idea del peronismo como «revolución pacífica», una transformación social sin violencia ni conflictos; idea que también aparecía de modo explícito en Juan y Eva, y que se alinea fácilmente con 
el discurso kirchnerista, cargado de una retórica épica (Montero, 2012). Si la Eva Perón de 1996 permitió criticar la defección menemista, el Perón de 2012 parece construido a la medida del kirchnerismo. La película funciona como divulgadora de algunas ideas de Perón, seleccionadas a tono con el clima de época, signado por la muerte de Néstor Kirchner y el giro hacia la izquierda del discurso kirchnerista.

Esa sintonía con la época puede resumirse en la definición que el propio personaje enuncia: «Soy más amigo de Fidel que de Franco». Esa frase sintetiza la toma de posición del protagonista frente a la disyuntiva central que enfrenta en la película: la planteada por las tensiones entre peronistas de izquierda y peronistas de derecha ${ }^{6}$. El Perón de Laplace también afirma en tercera persona que «Perón es la opción para el socialismo nacional» y elogia al «Che» Guevara («Era un hombre necesario»; «Nos hubiéramos llevado muy bien»). Otro elemento que se destaca de su pensamiento es el continentalismo, en tiempos de retorno del discurso en favor de la integración latinoamericana (la película se realizó mientras la región aún atravesaba la denominada «marea rosa», con los gobiernos de Hugo Chávez en Venezuela, Dilma Rousseff en Brasil, José Mujica en Uruguay, Rafael Correa en Ecuador y Evo Morales en Bolivia).

Según el guion, la única falta que se puede atribuir al líder es la ingenuidad. Probablemente esa sea la principal falencia del film: la figuración de este Perón infalible, recortado a la medida del relato político del presente, lo que impide la comprensión histórica. La construcción de este Perón de izquierda, entusiasmado con los jóvenes y que se reivindica como revolucionario, obtura la explicación de lo que vendrá después: la Triple A (Alianza Anticomunista Argentina), la eventual delegación de poder en Isabel y López Rega, la espiral de violencia, el golpe militar de 1976.

El personaje de López Rega (Adolfo Yanelli) es presentado como un hombrecito esotérico, inquietante y desequilibrado, en quien ninguna

6 La posición de Perón frente a las disputas internas del peronismo, que en el discurso histórico aparece mucho más ambigua, en el film resulta clara. Poco antes del regreso a la Argentina, el personaje de Jorge Antonio (Javier Lombardo) le plantea al protagonista el gran dilema de entonces: «Hay que saber cuál es la nueva pata en la Argentina. Por un lado están los jóvenes de la resistencia; por otro lado está Vandor, el ala sindical». Perón le responde: «La rebeldía de la juventud siempre es una garantía». En otras escenas vemos a Perón afirmando que los jóvenes deben suplantarlo, elogiando a la «juventud maravillosa» o distinguiendo: «Con ellos me entiendo mejor, los viejos tiran todo para atrás». Cualquier espectador más o menos informado está al tanto de las consecuencias violentas de los enfrentamientos entre el peronismo de izquierda (en la película, «los jóvenes») y el peronismo de derecha («los viejos»). Minimizando esas tensiones, una de las últimas escenas del film muestra una convivencia armoniosa entre los distintos sectores, con sus referentes reunidos en una mesa cantando la «Marcha peronista», lo que apenas suscita un chiste de Perón («Cuando los vi a todos juntos pensé que esto terminaba a los tiros», dice, y todos ríen, en una escena propia de una comedia familiar). 
persona razonable hubiera depositado la más mínima confianza: resulta muy difícil reponer el hueco entre lo que la película nos muestra y la violencia política que se desatará en la Argentina a partir de 1974, con López Rega en la cima del poder.

En esta misma línea opera la construcción caricaturesca de Isabel (Victoria Carreras), presentada como una mujer tonta, manipulable, infantil e inútil. La película le atribuye a Isabel toda la responsabilidad por el ascenso de López Rega (ella lo conoce en la gira que realiza por Argentina en 1965) y desliga en ese sentido a Perón. El guion ridiculiza sistemáticamente a Isabel: ese mecanismo alcanza su punto más alto en una escena que la muestra declamando - con su acento híbrido, entre peninsular y rioplatense- un viejo discurso de Evita, mientras López Rega realiza rituales para «transmitir» a la tercera esposa de Perón el «espíritu» de la segunda.

Esa es la principal función de la coprotagonista: ofrecer la contracara - degradada, paródica - de Evita. En este biopic, ubicado cronológicamente varios años después de la muerte de Eva, su presencia ingresa de dos maneras: por medio de su cadáver y de su libro, La razón de mi vida, que aparece dos veces (al principio, cuando Perón renuncia a la presidencia y prepara su valija, y más tarde cuando el protagonista le regala un ejemplar a su amiga Sofía, a quien también le ha obsequiado el Martín Fierro). Las comparaciones no se limitan a equiparar el poema clásico de José Hernández con el libro de Evita: en otra escena, Sofía compara a Evita con Gandhi y Einstein (ella considera que solo este tipo de personajes son dignos de escribir autobiografías).

Las peripecias del cadáver de Evita son un componente central del mito (Vezzetti, 1997). En el film, ese cuerpo aparece solo de modo fragmentario: el rostro herido, el pelo rubio que Isabel peina mientras elogia su belleza. El film incluye una escena en la que escuchamos una descripción minuciosa del estado del cadáver cuando es devuelto a Perón («el pecho, acuchillado en cuatro lugares; las rótulas fracturadas; un dedo de la mano cortado; el cuello prácticamente seccionado; un gran tajo en la mejilla y otro en el brazo...»), tomada de un comunicado difundido por las hermanas de Eva en 1985.

Al final, Perón se despide de Sofía con una cita de La razón de mi vida, que subraya la identificación entre Perón y Evita a partir de la muerte, asimilando sus respectivos «sacrificios»: «Pienso que no debe ser muy difícil morir por una causa que se ama. O simplemente: morir por amor». Como en Juan y Eva, reaparece aquí la idea de que el peronismo es, ante todo, una cuestión afectiva: de lo que se trata es del amor.

En su estudio sobre los biopics británicos, Robinson plantea que a partir de fines del siglo XX «el tratamiento de los personajes biográficos viró 
desde el "gran hombre" hacia el hombre"herido"» (2016, p. 23), es decir, un sujeto atravesado por contradicciones y claroscuros. Nada de este viraje se ve en Puerta de hierro: ya en una de las primeras escenas Perón cita a Nietzsche para decir que «solo a los grandes hombres suelen pasarles cosas terribles», obviamente considerándose a sí mismo entre esos grandes. Hacia el final, el personaje da un paso más y compara su situación de exilio con la lejanía de Dios: «Dios es Dios porque nadie lo ve. Si viéramos a Dios todos los días le faltaríamos el respeto, y hasta no faltaría algún imbécil que quisiera reemplazarlo».

Tenemos, en definitiva, a un Perón marmóreo, con estatura de prócer. Probablemente Puerta de hierro no vale tanto como película sobre el peronismo - no contribuye demasiado a la comprensión del movimiento ni de su devenir histórico-, sino más bien como película peronista. Esa posición de enunciación se termina de asumir en el último plano: vemos a Perón solo en su escritorio, pensando; luego se pone de pie, levanta la vista y mira fijo a la cámara. Como el final de Juan y Eva, que trascendía la ficción para asumir rasgos documentales, este plano final cuestiona las fronteras genéricas del film, quebrando una de las convenciones básicas de la ficción. La mirada a cámara es una interpelación directa al espectador, un último gesto que explicita a quién está dirigida esta narración: al militante peronista.

\section{Conclusiones}

Juan y Eva y Puerta de hierro no solo comparten un clima de época -el del tercer gobierno kirchnerista-, sino también la elección del hogar como principal espacio narrativo, aun cuando el modo de presentar la acción en ese espacio es muy diferente: en De Luque tenemos el minimalismo de la vida cotidiana; en Laplace, en cambio, todo está permeado por el discurso político.

Comparten, también, la ausencia de todo atisbo de crítica o cuestionamiento a las figuras de Perón y Evita $-\mathrm{y}$, en ese sentido, resultan menos matizadas que la Eva Perón de Desanzo o la Evita de Mignogna-. Son biopics que no abordan a sus personajes desde la indagación, sino desde una convicción partidaria: aunque Juan y Eva es menos explícita y menos mimética que Puerta de hierro, en ninguno de los casos se plantean interrogantes acerca de estas figuras históricas. No hay, en otras palabras, profanación del mito para habilitar una lectura histórica:

Inscribir en lo mítico una reflexión sobre el pasado —además de ser una estética consoladora para un tiempo cultural sin mitos- es una confesión de la pérdida en su manera más extrema. Lo es en la medida en que suspende el tiempo en la secuencia narrativa y extingue 
lo auténticamente histórico, reduciéndolo al momento de la contemplación emocional, más adecuada al consumo nostálgico que a generar una distancia reflexiva (Amado, 2009, p. 80).

Juan y Eva y Puerta de hierro renuncian a esa distancia reflexiva que Amado señala como requisito para la comprensión histórica. No hay aquí margen para la ambigüedad, sino el despliegue de una idealización que apunta sobre todo a sostener una lectura militante del peronismo.

En ambos films, el peronismo se enuncia como una revolución pacífica: esa revolución solo aparece en el discurso de los personajes, pero resulta escatimada en la pantalla; se dice pero no se muestra. Desde la elección del género cinematográfico (en Juan y Eva) o desde los discursos de los personajes (en Puerta de hierro), ambos films presentan al peronismo como un asunto afectivo, una relación amorosa entre Perón, Evita y el pueblo (peronista).

En ocasiones, el género biopic permite abordar una figura mítica para humanizarla. Los dos films que analizamos aquí realizan la operación contraria: alimentan el mito; prometen asomarse a un aspecto nunca visto o a una porción menos transitada de la historia, pero solo lo hacen superficialmente, para volver a decir lo que ya ha sido dicho. Contribuyen a la mitificación de la historia antes que a su comprensión: en ese sentido, son films más sentimentales que políticos. Es curioso que, en los años de democracia transcurridos entre la película de Mignogna (de 1984) y las de De Luque y Laplace, los relatos sobre Evita y Perón hayan perdido complejidad; también es llamativo que la voluntad de ecuanimidad de aquella película de los albores democráticos hoy parezca un gesto anacrónico o, en todo caso, ingenuo. A diferencia de las búsquedas narrativas de los años 80 y 90 en torno a Evita y Perón, los biopics peronistas de la década de 2010 ya no buscan abrir un debate: aspiran, más bien, a ratificar las creencias de los convencidos.

\section{Contribución del autor}

Alfredo Dillon ha participado en la elaboración, la redacción y el consentimiento de la versión final del presente artículo.

\section{Fuente de financiamiento}

Universidad Católica Argentina.

\section{Conflictos de interés}

Ninguno. 


\section{REFERENCIAS BIBLIOGRÁFICAS}

Aguilar, G. (2010). Otros mundos. Un ensayo sobre el nuevo cine argentino. Buenos Aires: Santiago Arcos.

Aguilar, G. (2015). Más allá del pueblo. Imágenes, indicios y políticas del cine. Buenos Aires: Fondo de Cultura Económica.

Altman, R. (2000). Los géneros cinematográficos. Barcelona: Paidós.

Amado, A. (2009). La imagen justa. Cine argentino y política (1980-2007). Buenos Aires: Colihue.

Arfuch, L. (2002). El espacio biográfico. Dilemas de la subjetividad contemporánea. Buenos Aires: Fondo de Cultura Económica.

Arlanch, F. (2006). La struttura drammaturgica del film biografico nel cinema di Hollywood e nella televisione italiana (tesis de doctorado). Università Cattolica del Sacro Cuore.

Bingham, D. (2010). Whose lives are they anyway? The biopic as contemporary film genre. New Brunswick: Rutgers University Press.

Blanchot, M. (1974). El fin del héroe. En El diálogo inconcluso. Caracas: Monte Ávila Editores.

Blejman, M. (2004, 6 de junio). «Hacía años que quería filmar el peronismo». Entrevista a Héctor Olivera. Página 12. Recuperado de https://www. pagina12.com.ar/diario/espectaculos/6-36304-2004-06-06.html

Cortés Rocca, P. y Kohan, M. (1998). Imágenes de vida, relatos de muerte. Eva Perón: cuerpo y política. Buenos Aires: Beatriz Viterbo.

Custen, G. (1992). Bio/pics: How Hollywood constructed public history. New Brunswick: Rutgers University Press.

De Luque, P. (2011, 11 de octubre). Lo que se pone en evidencia. Página 12. Recuperado de https://www.pagina12.com.ar/diario/suplementos/espectaculos/2-23167-2011-10-11.html

Fontanel, R. (2016). Le biopic du sportif américain. Revue LISA e-journal. Littératures, Histoire des Idées, Images et Sociétés du Monde Anglophone, XIV(2). Recuperado de https://journals.openedition.org/lisa/8965

Galasso, N. (2005). Perón. Formación, ascenso y caída (1893-1955). Buenos Aires: Colihue.

Greimas, A. J. (1971). Semántica estructural. Madrid: Gredos.

Hernández Corchete, S. (2011). De las biografías ejemplares de Televisión Española a los biopics de éxito de las cadenas privadas. Un recorrido histórico por la biografía televisiva en España. En G. Camarero (Ed.), La biografía fílmica: actas del Segundo Congreso Internacional de Historia y Cine (pp. 349-367). Madrid: T\&B Editores. 
Instituto Nacional de Cine y Artes Audiovisuales (INCAA) (2011, 2013). Anuarios 2011 y 2013 de la industria del cine. Recuperado de http://fiscalizacion.incaa.gov.ar/index_publicaciones.php

Kohan, M. (2005). Narrar a San Martín. Buenos Aires: Adriana Hidalgo.

Kriger, C. (2009). Cine y peronismo. El estado en escena. Buenos Aires: Siglo $\mathrm{XXI}$.

López, M. y Rodríguez, A. (2009). Un país de película. La historia argentina que el cine nos contó. Buenos Aires: Del Nuevo Extremo.

Lyotard, J. F. (1989). La condición posmoderna: informe sobre el saber. Buenos Aires: Teorema.

Montero, A. (2012). ¡Y al final un día volvimos! Los usos de la memoria en el discurso kirchnerista (2003-2007). Buenos Aires: Prometeo.

Navarro, M. (Comp.) (2002). Evita. Mitos y representaciones. Buenos Aires: Fondo de Cultura Económica.

Plotkin, M. (2007). El día que se inventó el peronismo: la construcción del 17 de octubre. Buenos Aires: Sudamericana.

Polaschek, B. (2013). The postfeminist biopic: Narrating the lives of Plath, Kahlo, Woolf and Austen. Londres: Palgrave Macmillan.

Prividera, N. (2016). El país del cine. Para una historia política del nuevo cine argentino. Córdoba: Los Ríos.

Prysthon, A. (2013). La sensibilidad de lo banal en el cine contemporáneo. En J. Andermann y Á. Fernández Bravo (Comp.), La escena y la pantalla. Cine contemporáneo y el retorno de lo real (pp. 93-109). Buenos Aires: Colihue.

Robinson, M. (2016). Mapping the British biopic: Evolution, conventions, reception and masculinities (tesis de doctorado). University of the West of England, Bristol.

Rosenstone, R. (2006). History on film/Film on History. Edinburgh: Pearson Longman.

Sánchez Noriega, J. L. (2012). «Construcciones fílmicas de personajes históricos en el cine español (2000-2010)». Comunicación y Sociedad, XXV(2), pp. 57-84.

Sarlo, B. (2005). Tiempo pasado. Cultura de la memoria y giro subjetivo. Buenos Aires: Siglo XXI.

Trombetta, J. (2015). Las representaciones cinematográficas y teatrales de Eva Perón en el período 1983-2014. De la figura al mito (tesis de doctorado). Facultad de Filosofía y Letras de la Universidad de Buenos Aires.

Vezzetti, H. (1997). El cuerpo de Eva Perón. Punto de Vista, 58, pp. 3-8. 
Vidal, B. (2014). The biopic and its critical contexts. En T. Brown y B. Vidal (Eds.), The biopic in contemporary film culture. New York: Routledge.

Recibido: $29 / 06 / 20$

Aceptado: 27/07/20 